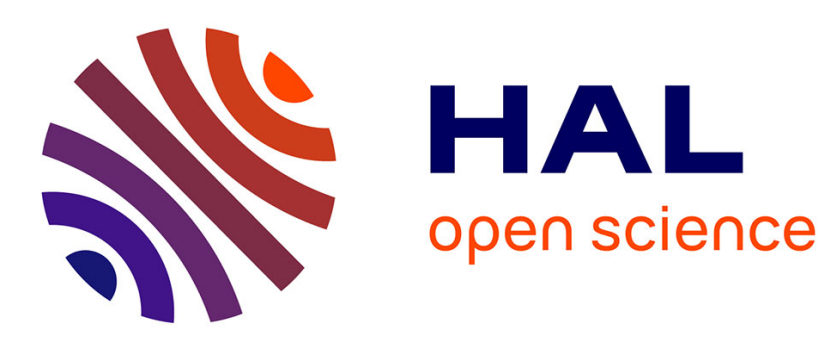

\title{
Money in the Production Function: A New Keynesian DSGE Perspective
}

\author{
Jonathan Benchimol
}

\section{To cite this version:}

Jonathan Benchimol. Money in the Production Function : A New Keynesian DSGE Perspective. 2011. hal-00795547

\section{HAL Id: hal-00795547 \\ https://essec.hal.science/hal-00795547}

Preprint submitted on 28 Feb 2013

HAL is a multi-disciplinary open access archive for the deposit and dissemination of scientific research documents, whether they are published or not. The documents may come from teaching and research institutions in France or abroad, or from public or private research centers.
L'archive ouverte pluridisciplinaire HAL, est destinée au dépôt et à la diffusion de documents scientifiques de niveau recherche, publiés ou non, émanant des établissements d'enseignement et de recherche français ou étrangers, des laboratoires publics ou privés. 


\section{Money in the Production Function: A New Keynesian DSGE Perspective}

\section{Research Center \\ ESSEC Working Paper 1304}

2013

Jonathan Benchimol 


\title{
Money in the production function: a new Keynesian DSGE perspective*
}

\author{
Jonathan Benchimol ${ }^{\dagger}$
}

This version: December 8th, 2011

First version: June 27th, 2010

\begin{abstract}
This paper proposes a New Keynesian Dynamic Stochastic General Equilibrium (DSGE) model where real money balances enter the production function. By using a Bayesian analysis, our model shows that money is not an omitted input to the production process and rejects the decreasing returns to scale hypothesis. Our simulations suggest that money plays a negligible role in the dynamics of output and inflation, despite its inclusion in the production function. In addition, we introduce the flexible-price real money balances concept.

Keywords: Money in the production function, DSGE, Bayesian estimation.

JEL Classification Number: E23, E31, E51.
\end{abstract}

${ }^{*}$ For helpful comments and suggestions, I would like to thank André Fourçans, Christian Bordes, Laurent Clerc, Marc-Alexandre Sénégas, Gunther Capelle-Blancard, and two anonymous referees.

${ }^{\dagger}$ PhD Program, ESSEC Business School, Avenue Bernard Hirsch, 95021 Cergy Pontoise Cedex 2, France, and CES-University Paris 1 Panthéon-Sorbonne, 106-112 Boulevard de l'Hôpital, 75647 Paris Cedex 13, France. Email: jonathan.benchimol@essec.edu 


\section{Introduction}

The theoretical motivation for empirical implementations of money in the production function originates from monetary growth models of Levhari and Patinkin (1968), Friedman (1969), Johnson (1969) and Stein (1970), which include money directly in the production function. Firms hold money to facilitate production, on the grounds that money enables them to economize the use of other inputs, and spares the cost of running short of cash (Fischer, 1974).

Real cash balances are at least in part a factor of production. To take a trivial example, a retailer can economize on his average cash balances by hiring an errand boy to go to the bank on the corner to get change for large bills tendered by customers. When it costs ten cents per dollar per year to hold an extra dollar of cash, there will be a greater incentive to hire the errand boy, that is, to substitute other productive resources for cash. This will mean both a reduction in the real flow of services from the given productive resources and a change in the structure of production, since different productive activities may differ in cash-intensity, just as they differ in labor - or land - intensity.

Milton Friedman (1969)

In an old article, Sinai and Stokes (1972) present a very interesting test of the hypothesis that money enters the production function, and they suggest that real balances could be a missing variable that contributes to the attribution of the unexplained residual to technological changes. Ben-Zion and Ruttan (1975) conclude that money as a factor of demand seems to play an important role in explaining induced technological changes.

Short (1979) develops structural models based on Cobb and Douglas (1928) and generalized translog production functions, both of which provide a more complete theoretical framework for analyzing the role of money in the production process. The empirical results obtained by estimating these two models indicate that the relationship between real cash balances and output, even after correcting for any simultaneity bias, is positive and statistically significant. The results suggest that it is theoretically appropriate to include a real cash balances variable as a factor input in a production function in order to capture the productivity gains derived from using money.

You (1981) finds that the unexplained portion of output variation virtually vanishes with real balances included in the production function. Besides labor and capital, real money balances turn out to be an important factor of 
production, especially for developing countries. The results in Khan and Ahmad (1985) are consistent with the hypothesis that real money balances are an important factor of production. Sephton (1988) shows that real balances are a valid factor of production within the confines of a CES production function. Hasan and Mahmud (1993) also support the hypothesis that money is an important factor in the production function and that there are potential supply side effects of a change in the interest rate.

Recent developments in econometrics regarding co-integration and error correction models provide a rich environment in which the role of money in the production function can be reexamined. In a co-integrated space, Moghaddam (2010) presents empirical evidence indicating that different definitions of money play an input role in the Cobb and Douglas (1928) production function.

At the same time, Clarida et al. (1999), Woodford (2003) and Galí (2008) develop New Keynesian Dynamic Stochastic General Equilibrium (DSGE) models to explain the dynamics of the economy. However, no studies use money as an input in the production function in New Keynesian DSGE models.

This article departs from the existing theoretical and empirical literature by specifying a New Keynesian DSGE model where money enters the production function. This feature generates a new inflation dynamics where money could play a significant role. Following Galí (2008), we introduce the new concept of flexible-price real money balances in order to close the model. We also analyze the dynamics of the economy by using Bayesian estimations and simulations to confirm or reject the potential role of money in the dynamics of the Eurozone. Moreover, this paper intends to solve the now-old controversial hypothesis about constant returns to scale of money in the production function initiated by Sinai and Stokes (1972).

Notice that in this paper, because data are available, we voluntary do not distinguish money for productive and nonproductive use as in Benhabib et al. (2001).

After describing the theoretical set up in Section 2, we calibrate and estimate two models (constrained i.e. constant returns to scale, and unconstrained i.e. decreasing returns to scale) of the Euro area using Bayesian techniques in 3. Impulse response functions and variance decomposition are analyzed in Section 4, and we solve the choice of the returns to scale hypothesis by comparing the two models of this paper in Section 5. Section 6 concludes, and Section 7 presents additional results. 


\section{The model}

The model consists of households that supply labor, purchase goods for consumption, and hold money and bonds, and firms that hire labor and produce and sell differentiated products in monopolistically competitive goods markets. Each firm sets the price of the good it produces, but not all firms reset their respective prices each period. Households and firms behave optimally: households maximize the expected present value of utility, and firms maximize profits. There is also a central bank that controls the nominal interest rate. This model is inspired by Smets and Wouters (2003), Galí (2008), and Walsh (2010).

\subsection{Households}

We assume a representative infinitely-lived household, seeking to maximize

$$
E_{t}\left[\sum_{k=0}^{\infty} \beta^{k} U_{t+k}\right]
$$

where $U_{t}$ is the period utility function, and $\beta<1$ is the discount factor.

We assume the existence of a continuum of goods represented by the interval $[0,1]$. The household decides how to allocate its consumption expenditures among the different goods. This requires that the consumption index, $C_{t}$, be maximized for any given level of expenditures. $\forall t \in \mathbb{N}$, and conditionally on such optimal behavior, the period budget constraint takes the form

$$
P_{t} C_{t}+M_{t}+Q_{t} B_{t} \leq B_{t-1}+W_{t} N_{t}+M_{t-1}
$$

where $P_{t}$ is an aggregate price index, $M_{t}$ is the quantity of money holdings at time $t, B_{t}$ is the quantity of one-period nominally riskless discount bonds purchased in period $t$ and maturing in period $t+1$ (each bond pays one unit of money at maturity and its price is $Q_{t}$, so that the short term nominal rate $i_{t}$ is approximately equals to $\left.-\log Q_{t}\right), W_{t}$ is the nominal wage, and $N_{t}$ is hours of work (or the measure of household members employed).

The above sequence of period budget constraints is supplemented with a solvency condition, such as $\forall t \lim _{n \longrightarrow \infty} E_{t}\left[B_{n}\right] \geq 0$.

Preferences are measured with a common time-separable utility function. Under the assumption of a period utility given by

$$
U_{t}=e^{\varepsilon_{t}^{p}}\left(\frac{C_{t}^{1-\sigma}}{1-\sigma}+\frac{\gamma e^{\varepsilon_{t}^{m}}}{1-\nu}\left(\frac{M_{t}}{P_{t}}\right)^{1-\nu}-\frac{\chi N_{t}^{1+\eta}}{1+\eta}\right)
$$


consumption, labor supply, money demand and bond holdings are chosen to maximize (1) subject to (2) and the solvency condition. This MIU utility function depends positively on the consumption of goods, $C_{t}$, positively on real money balances, $\frac{M_{t}}{P_{t}}$, and negatively on labor $N_{t}$. $\sigma$ is the coefficient of relative risk aversion of households or the inverse of the intertemporal elasticity of substitution, $\nu$ is the inverse of the elasticity of money holdings with respect to the interest rate, and $\eta$ is the inverse of the elasticity of work effort with respect to the real wage (inverse of the Frisch elasticity of labor supply).

The utility function also contains two structural shocks: $\varepsilon_{t}^{p}$ is a general shock to preferences that affects the intertemporal substitution of households (preference shock) and $\varepsilon_{t}^{m}$ is a money demand shock. $\gamma$ and $\chi$ are positive scale parameters.

This setting leads to the following conditions ${ }^{1}$, which, in addition to the budget constraint, must hold in equilibrium. The resulting log-linear version of the first order condition corresponding to the demand for contingent bonds implies that

$$
c_{t}=E_{t}\left[c_{t+1}\right]-\frac{1}{\sigma}\left(i_{t}-E_{t}\left[\pi_{t+1}\right]-\rho_{c}\right)-\sigma^{-1} E_{t}\left[\Delta \varepsilon_{t+1}^{p}\right]
$$

where the lowercase letters denote the logarithm of the original aggregated variables, $\rho_{c}=-\log (\beta)$, and $\Delta$ is the first-difference operator.

The demand for cash that follows from the household's optimization problem is given by

$$
\varepsilon_{t}^{m}+\sigma c_{t}-\nu m p_{t}-\rho_{m}=a_{2} i_{t}
$$

where $m p_{t}=m_{t}-p_{t}$ are the log-linearized real money balances, $\rho_{m}=$ $-\log (\gamma)+a_{1}, a_{1}$ and $a_{2}$ are resulting terms of the first-order Taylor approximation of $\log \left(1-Q_{t}\right)=a_{1}+a_{2} i_{t}$. More precisely, if we compute our first-order Taylor approximation around the steady-state interest rate, $\frac{1}{\beta}$, we obtain $a_{1}=\log \left(1-\exp \left(-\frac{1}{\beta}\right)\right)-\frac{\frac{1}{\beta}}{e^{\frac{1}{\beta}}-1}$, and $a_{2}=\frac{1}{e^{\frac{1}{\beta}}-1}$.

Real cash holdings depend positively on consumption, with an elasticity equal to $\sigma / \nu$, and negatively on the nominal interest rate $\left(\frac{1}{\beta}>1\right.$ which implies that $\left.a_{2}>0\right)$. Below, we take the nominal interest rate as the central bank's policy instrument.

In the literature, due to the assumption that consumption and real money balances are additively separable in the utility function, cash holdings do not enter any of the other structural equations: accordingly, the above equation becomes a recursive function of the rest of the system of equations. However,

\footnotetext{
${ }^{1}$ See Appendix 7.A.
} 
as in Sinai and Stokes (1972), Subrahmanyam (1980), or Khan and Ahmad (1985), because real money balances enter the aggregate supply, we will use this money demand equation (eq. 5) in order to solve the equilibrium of our model. See for instance Ireland (2004) and Benchimol and Fourçans (2012) for models in which money balances enter the aggregate demand equation without entering the production function.

The resulting log-linear version of the first order condition corresponding to the optimal consumption-leisure arbitrage implies that

$$
w_{t}-p_{t}=\sigma c_{t}+\eta n_{t}-\rho_{n}
$$

where $\rho_{n}=-\log (\chi)$.

Finally, these equations represent the Euler condition for the optimal intratemporal allocation of consumption (eq. 4), the intertemporal optimality condition setting the marginal rate of substitution between money and consumption equal to the opportunity cost of holding money (eq. 5), and the intratemporal optimality condition setting the marginal rate of substitution between leisure and consumption equal to the real wage (eq. 6).

\section{$2.2 \quad$ Firms}

We assume a continuum of firms indexed by $i \in[0,1]$. Each firm produces a differentiated good, but they all use an identical technology, represented by the following money-in-the-production function

$$
Y_{t}(i)=A_{t}\left(\frac{M_{t}}{P_{t}}\right)^{\alpha_{m}} N_{t}(i)^{1-\alpha_{n}}
$$

where $A_{t}=\exp \left(\varepsilon_{t}^{a}\right)$ represents the level of technology, assumed to be common to all firms and to evolve exogenously over time.

All firms face an identical isoelastic demand schedule, and take the aggregate price level, $P_{t}$, and aggregate consumption index, $C_{t}$, as given. As in the standard Calvo (1983) model, our generalization features monopolistic competition and staggered price setting. At any time $t$, only a fraction $1-\theta$ of firms, with $0<\theta<1$, can reset their prices optimally, while the remaining firms index their prices to lagged inflation.

\subsection{Price dynamics}

Let's assume a set of firms that do not reoptimize their posted price in period $t$. As in Galí (2008), using the definition of the aggregate price level and the fact that all firms that reset prices choose an identical price, $P_{t}^{*}$, 
leads to $P_{t}=\left[\theta P_{t-1}^{1-\varepsilon}+(1-\theta)\left(P_{t}^{*}\right)^{1-\varepsilon}\right]^{\frac{1}{1-\varepsilon}}$. Dividing both sides by $P_{t-1}$ and $\log$-linearizing around $P_{t}^{*}=P_{t-1}$ yields

$$
\pi_{t}=(1-\theta)\left(p_{t}^{*}-p_{t-1}\right)
$$

In this set up, we do not assume inertial dynamics of prices. Inflation results from the fact that firms reoptimizing their price plans in any given period, choose a price that differs from the economy's average price in the previous period.

\section{$2.4 \quad$ Price setting}

A firm reoptimizing in period $t$ chooses the price $P_{t}^{*}$ that maximizes the current market value of the profits generated while that price remains effective. We solve this problem to obtain a first-order Taylor expansion around the zero inflation steady state of the firm's first-order condition, which leads to

$$
p_{t}^{*}-p_{t-1}=(1-\beta \theta) \sum_{k=0}^{\infty}(\beta \theta)^{k} E_{t}\left[\widehat{m c}_{t+k \mid t}+\left(p_{t+k}-p_{t-1}\right)\right]
$$

where $\widehat{m c}_{t+k \mid t}=m c_{t+k \mid t}-m c$ denotes the log deviation of marginal cost from its steady state value $m c=-\mu$, and $\mu=\log (\varepsilon /(\varepsilon-1))$ is the $\log$ of the desired gross markup.

\subsection{Equilibrium}

Market clearing in the goods market requires $Y_{t}(i)=C_{t}(i)$ for all $i \in[0,1]$ and all $t$. Aggregate output is defined as $Y_{t}=\left(\int_{0}^{1} Y_{t}(i)^{1-\frac{1}{\varepsilon}} d i\right)^{\frac{\varepsilon}{\varepsilon-1}}$; it follows that $Y_{t}=C_{t}$ must hold for all $t$. One can combine the above goods market clearing condition with the consumer's Euler equation to yield the equilibrium condition

$$
y_{t}=E_{t}\left[y_{t+1}\right]-\sigma^{-1}\left(i_{t}-E_{t}\left[\pi_{t+1}\right]-\rho_{c}\right)-\sigma^{-1} E_{t}\left[\Delta \varepsilon_{t+1}^{p}\right]
$$

Market clearing in the labor market requires $N_{t}=\int_{0}^{1} N_{t}(i) d i$. Using (7) leads to

$$
\begin{aligned}
N_{t} & =\int_{0}^{1}\left(\frac{Y_{t}(i)}{A_{t}\left(\frac{M_{t}}{P_{t}}\right)^{\alpha_{m}}}\right)^{\frac{1}{1-\alpha_{n}}} d i \\
& =\left(\frac{Y_{t}}{A_{t}\left(\frac{M_{t}}{P_{t}}\right)^{\alpha_{m}}}\right)^{\frac{1}{1-\alpha_{n}}} \int_{0}^{1}\left(\frac{P_{t}(i)}{P_{t}}\right)^{-\frac{\varepsilon}{1-\alpha_{n}}} d i
\end{aligned}
$$


where the second equality follows from the demand schedule and the goods market clearing condition. Taking logs leads to

$$
\left(1-\alpha_{n}\right) n_{t}=y_{t}-\varepsilon_{t}^{a}-\alpha_{m} m p_{t}+d_{t}
$$

where $d_{t}=\left(1-\alpha_{n}\right) \log \left(\int_{0}^{1}\left(\frac{P_{t}(i)}{P_{t}}\right)^{-\frac{\varepsilon}{1-\alpha_{n}}} d i\right)$, and $d i$ is a measure of price (and, hence, output) dispersion across firms. Following Galí (2008), in a neighborhood of the zero inflation steady state, $d_{t}$ is equal to zero up to a first-order approximation.

Hence, one can write the following approximate relation between aggregate output, employment, real money balances and technology as

$$
y_{t}=\varepsilon_{t}^{a}+\left(1-\alpha_{n}\right) n_{t}+\alpha_{m} m p_{t}
$$

An expression is derived for an individual firm's marginal cost in terms of the economy's average real marginal cost. With the marginal product of labor,

$$
\begin{aligned}
m p n_{t} & =\log \left(\frac{\partial Y_{t}}{\partial N_{t}}\right) \\
& =\log \left(A_{t}\left(\frac{M_{t}}{P_{t}}\right)^{\alpha_{m}}\left(1-\alpha_{n}\right) N_{t}^{-\alpha_{n}}\right) \\
& =\varepsilon_{t}^{a}+\alpha_{m} m p_{t}+\log \left(1-\alpha_{n}\right)-\alpha_{n} n_{t}
\end{aligned}
$$

and the marginal product of real money balances,

$$
\begin{aligned}
m p m p_{t} & =\log \left(\frac{\partial Y_{t}}{\partial \frac{M_{t}}{P_{t}}}\right) \\
& =\log \left(A_{t} \alpha_{m}\left(\frac{M_{t}}{P_{t}}\right)^{\alpha_{m}-1} N_{t}^{1-\alpha_{n}}\right) \\
& =\varepsilon_{t}^{a}+\log \left(\alpha_{m}\right)+\left(\alpha_{m}-1\right) m p_{t}+\left(1-\alpha_{n}\right) n_{t}
\end{aligned}
$$

we obtain an expression of the marginal cost

$$
\begin{aligned}
m c_{t}= & \left(w_{t}-p_{t}\right)-m p n_{t}-m p m p_{t} \\
= & w_{t}-p_{t}+\frac{2 \alpha_{n}-1}{1-\alpha_{n}} y_{t}+\frac{1-\alpha_{m}-\alpha_{n}}{1-\alpha_{n}} m p_{t} \\
& -\frac{1}{1-\alpha_{n}} \varepsilon_{t}^{a}-\log \left(\alpha_{m}\left(1-\alpha_{n}\right)\right)
\end{aligned}
$$

for all $t$, where the second equality defines the economy's average marginal product of labor, $m p n_{t}$, and the economy's average marginal product of real 
money balances, $m p m p_{t}$, in a way that is consistent with (12). Using the fact that $m c_{t+k \mid t}=\left(w_{t+k}-p_{t+k}\right)-m p n_{t+k \mid t}$,

$$
\begin{aligned}
m c_{t+k \mid t}= & \left(w_{t+k}-p_{t+k}\right)+\frac{2 \alpha_{n}-1}{1-\alpha_{n}} y_{t+k \mid t} \\
& +\frac{1-\alpha_{m}-\alpha_{n}}{1-\alpha_{n}} m p_{t+k}-\frac{1}{1-\alpha_{n}} \varepsilon_{t+k}^{a}-\log \left(\alpha_{m}\left(1-\alpha_{n}\right)\right) \\
= & m c_{t+k}+\frac{2 \alpha_{n}-1}{1-\alpha_{n}}\left(y_{t+k \mid t}-y_{t+k}\right) \\
= & m c_{t+k}-\varepsilon \frac{2 \alpha_{n}-1}{1-\alpha_{n}}\left(p_{t}^{*}-p_{t+k}\right)
\end{aligned}
$$

where the second equality follows from the demand schedule, $C_{t}(i)=\left(\frac{P_{t}(i)}{P_{t}}\right)^{-\varepsilon} C_{t}$, combined with the market clearing condition $\left(y_{t}=c_{t}\right)$.

Substituting (13) into (9) and rearranging terms yields

$$
\begin{aligned}
p_{t}^{*}-p_{t-1} & =(1-\beta \theta) \sum_{k=0}^{\infty}(\beta \theta)^{k} E_{t}\left[\begin{array}{c}
\widehat{m c}_{t+k}-\varepsilon \frac{2 \alpha_{n}-1}{1-\alpha_{n}}\left(p_{t}^{*}-p_{t+k}\right) \\
+\left(p_{t+k}-p_{t-1}\right)
\end{array}\right] \\
p_{t}^{*}-p_{t-1} & =(1-\beta \theta) \Theta \sum_{k=0}^{\infty}(\beta \theta)^{k} E_{t}\left[\widehat{m c}_{t+k}\right]+\sum_{k=0}^{\infty}(\beta \theta)^{k} E_{t}\left[\pi_{t+k}\right]
\end{aligned}
$$

where $\Theta=\frac{1-\alpha_{n}}{1-\alpha_{n}+\varepsilon\left(2 \alpha_{n}-1\right)} \leq 1$.

Finally, combining (8) in (14) yields the inflation equation

$$
\pi_{t}=\beta E_{t}\left[\pi_{t+1}\right]+\lambda_{m c} \widehat{m c}_{t}
$$

where $\lambda_{m c}=\Theta \frac{(1-\theta)(1-\beta \theta)}{\theta}$ is strictly decreasing in the index of price stickiness, $\theta$, in the measure of decreasing returns, $\alpha_{n}$, and in the demand elasticity, $\varepsilon$.

Next, a relation is derived between the economy's real marginal cost and a measure of aggregate economic activity. Notice that, independent of the nature of price setting, average real marginal cost can be expressed as

$$
\begin{aligned}
m c_{t}= & \left(w_{t}-p_{t}\right)-m p n_{t}-m p m p_{t} \\
= & \left(\sigma y_{t}+\eta n_{t}-\rho_{n}\right)+\frac{2 \alpha_{n}-1}{1-\alpha_{n}} y_{t}+\frac{1-\alpha_{m}-\alpha_{n}}{1-\alpha_{n}} m p_{t} \\
& -\frac{1}{1-\alpha_{n}} \varepsilon_{t}^{a}-\log \left(\alpha_{m}\left(1-\alpha_{n}\right)\right) \\
= & \frac{\sigma\left(1-\alpha_{n}\right)+\eta+2 \alpha_{n}-1}{1-\alpha_{n}} y_{t}+\frac{1-(1+\eta) \alpha_{m}-\alpha_{n}}{1-\alpha_{n}} m p_{t} \\
& -\frac{1+\eta}{1-\alpha_{n}} \varepsilon_{t}^{a}-\log \left(\alpha_{m}\left(1-\alpha_{n}\right)\right)-\rho_{n}
\end{aligned}
$$


where derivation of the second and third equalities makes use of the household's optimality condition (6) and the (approximate) aggregate production relation (12).

Knowing that $\sigma>0, \alpha_{n} \leq 1$, and $\eta \geq 1$, it is obvious that $\sigma\left(1-\alpha_{n}\right)+$ $\eta+2 \alpha_{n}-1>0$. However, the inequality $1-(1+\eta) \alpha_{m}-\alpha_{n}>0$ coming from (16) appears unusual. In fact, it confirms some studies from Sinai and Stokes (Sinai and Stokes, 1975; Sinai and Stokes, 1977; Sinai and Stokes, 1981; Sinai and Stokes, 1989) concluding that the weight on labor is more important than the weight on money (or real money balances).

Furthermore, and as shown previously, under flexible prices the real marginal cost is constant and given by $m c=-\mu$. Defining the natural level of output, denoted by $y_{t}^{f}$, as the equilibrium level of output under flexible prices

$$
\begin{aligned}
m c= & \frac{\sigma\left(1-\alpha_{n}\right)+\eta+2 \alpha_{n}-1}{1-\alpha_{n}} y_{t}^{f}+\frac{1-(1+\eta) \alpha_{m}-\alpha_{n}}{1-\alpha_{n}} m p_{t}^{f} \\
& -\frac{1+\eta}{1-\alpha_{n}} \varepsilon_{t}^{a}-\log \left(\alpha_{m}\left(1-\alpha_{n}\right)\right)-\rho_{n}
\end{aligned}
$$

thus implying

$$
y_{t}^{f}=v_{a} \varepsilon_{t}^{a}+v_{m} m p_{t}^{f}+v_{c}
$$

where

$$
\begin{aligned}
v_{a}^{y} & =\frac{1+\eta}{\sigma+\eta+(1-\sigma) \alpha_{n}-1+\alpha_{n}} \\
v_{m}^{y} & =\frac{\alpha_{n}+\alpha_{m}(1+\eta)-1}{\sigma+\eta+(1-\sigma) \alpha_{n}-1+\alpha_{n}} \\
v_{c}^{y} & =\frac{\left(1-\alpha_{n}\right)\left(\log \left(\alpha_{m}\left(1-\alpha_{n}\right)\right)+\rho_{n}-\mu\right)}{\sigma+\eta+(1-\sigma) \alpha_{n}-1+\alpha_{n}}
\end{aligned}
$$

From (10), we obtain an expression for the natural interest rate,

$$
i_{t}^{f}=\rho_{c}+\sigma E_{t}\left[\Delta y_{t+1}^{f}\right]
$$

Then, by using (5) and (19), we obtain an expression of flexible-price real money balances

$$
m p_{t}^{f}=-\frac{a_{2} \sigma}{\nu} E_{t}\left[\Delta y_{t+1}^{f}\right]+\frac{\sigma}{\nu} y_{t}^{f}-\frac{a_{2} \rho_{c}+\rho_{m}}{\nu}+\frac{1}{\nu} \varepsilon_{t}^{m}
$$

Subtracting (17) from (16) yields

$$
\widehat{m c}_{t}=\frac{\sigma\left(1-\alpha_{n}\right)+\eta+2 \alpha_{n}-1}{1-\alpha_{n}}\left(y_{t}-y_{t}^{f}\right)+\frac{1-(1+\eta) \alpha_{m}-\alpha_{n}}{1-\alpha_{n}}\left(m p_{t}-m p_{t}^{f}\right)
$$


where $\widehat{m c}_{t}=m c_{t}-m c$ is the real marginal cost gap, $y_{t}-y_{t}^{f}$ is the output gap, and $m p_{t}-m p_{t}^{f}$ is the real money balances gap. By combining eq. (15) and eq. (21) we obtain our first equation relating inflation to its next period forecast, output gap and real money balances gap

$$
\pi_{t}=\beta E_{t}\left[\pi_{t+1}\right]+\psi_{x}\left(y_{t}-y_{t}^{f}\right)+\psi_{m}\left(m p_{t}-m p_{t}^{f}\right)
$$

where $\psi_{x}=\frac{(1-\theta)(1-\beta \theta)\left(\sigma\left(1-\alpha_{n}\right)+\eta+2 \alpha_{n}-1\right)}{\theta\left(1-\alpha_{n}+\varepsilon\left(2 \alpha_{n}-1\right)\right)}$ and $\psi_{m}=\frac{(1-\theta)(1-\beta \theta)\left(1-(1+\eta) \alpha_{m}-\alpha_{n}\right)}{\theta\left(1-\alpha_{n}+\varepsilon\left(2 \alpha_{n}-1\right)\right)}$.

The second key equation describing the equilibrium of the New Keynesian model is obtained from (10):

$$
y_{t}=E_{t}\left[y_{t+1}\right]-\sigma^{-1}\left(i_{t}-E_{t}\left[\pi_{t+1}\right]-\rho_{c}\right)-\sigma^{-1} E_{t}\left[\Delta \varepsilon_{t+1}^{p}\right]
$$

Henceforth (23) is referred to as the dynamic IS equation.

The third key equation describes behavior of the real money balances. Rearranging (5) yields

$$
m p_{t}=\frac{\sigma}{\nu} y_{t}-\frac{a_{2}}{\nu} i_{t}-\frac{\rho_{m}}{\nu}+\frac{1}{\nu} \varepsilon_{t}^{m}
$$

The last equation determines the interest rate through a standard smoothed Taylor-type rule,

$$
i_{t}=\left(1-\lambda_{i}\right)\left(\lambda_{\pi}\left(\pi_{t}-\pi^{*}\right)+\lambda_{x}\left(y_{t}-y_{t}^{f}\right)\right)+\lambda_{i} i_{t-1}+\varepsilon_{t}^{i}
$$

where $\lambda_{\pi}$ and $\lambda_{x}$ are policy coefficients reflecting the weight on inflation and on the output gap, and the parameter $0<\lambda_{i}<1$ captures the degree of interest rate smoothing. $\varepsilon_{t}^{i}$ is an exogenous ad hoc shock accounting for fluctuations of nominal interest rate.

All structural shocks are assumed to follow a first-order autoregressive process with an i.i.d. normal error term, such as $\forall k \in\{p, m, i, a\}, \varepsilon_{t}^{k}=$ $\mu_{k} \varepsilon_{t-1}^{k}+\omega_{k, t}$, where $\omega_{k, t} \sim N\left(0 ; \sigma_{k}\right)$.

\section{Results}

\subsection{DSGE model}

Our model consists of six equations and six dependent variables: inflation, nominal interest rate, output, flexible-price output, real money balances and its flexible-price counterpart. Flexible-price output and flexible-price real money balances are completely determined by shocks: flexible-price output is mainly driven by technology shocks (fluctuations in the output gap can 
be attributed to supply and demand shocks), whereas the flexible-price real money balances are driven by money shocks and flexible-price output.

$$
\begin{gathered}
y_{t}^{f}=v_{a}^{y} \varepsilon_{t}^{a}+v_{m}^{y} m p_{t}^{f}+v_{c}^{y} \\
m p_{t}^{f}=v_{y+1}^{m} E_{t}\left[\Delta y_{t+1}^{f}\right]+v_{y}^{m} y_{t}^{f}+v_{c}^{m}+\frac{1}{\nu} \varepsilon_{t}^{m} \\
\pi_{t}=\beta E_{t}\left[\pi_{t+1}\right]+\kappa_{x}\left(y_{t}-y_{t}^{f}\right)+\kappa_{m}\left(m p_{t}-m p_{t}^{f}\right) \\
y_{t}=E_{t}\left[y_{t+1}\right]-\sigma^{-1}\left(i_{t}-E_{t}\left[\pi_{t+1}\right]-\rho_{c}\right)-\sigma^{-1} E_{t}\left[\Delta \varepsilon_{t+1}^{p}\right] \\
m p_{t}=\frac{\sigma}{\nu} y_{t}-\frac{a_{2}}{\nu} i_{t}-\frac{\rho_{m}}{\nu}+\frac{1}{\nu} \varepsilon_{t}^{m} \\
i_{t}=\left(1-\lambda_{i}\right)\left(\lambda_{\pi}\left(\pi_{t}-\pi^{*}\right)+\lambda_{x}\left(y_{t}-y_{t}^{f}\right)\right)+\lambda_{i} i_{t-1}+\varepsilon_{t}^{i}
\end{gathered}
$$

where

$$
\begin{array}{ll}
v_{a}^{y}=\frac{1+\eta}{\sigma+\eta+(1-\sigma) \alpha_{n}-1+\alpha_{n}} & \kappa_{x}=\frac{(1-\theta)(1-\beta \theta)\left(\sigma\left(1-\alpha_{n}\right)+\eta+2 \alpha_{n}-1\right)}{\theta\left(1-\alpha_{n}+\varepsilon\left(2 \alpha_{n}-1\right)\right)} \\
v_{m}^{y}=\frac{\alpha_{n}+\alpha_{m}(1+\eta)-1}{\sigma+\eta+(1-\sigma) \alpha_{n}-1+\alpha_{n}} & \kappa_{m}=\frac{(1-\theta)(1-\beta \theta)\left(1-(1+\eta) \alpha_{m}-\alpha_{n}\right)}{\theta\left(1-\alpha_{n}+\varepsilon\left(2 \alpha_{n}-1\right)\right)} \\
v_{c}^{y}=\frac{\left(1-\alpha_{n}\right)\left(\log \left(\alpha_{m}\left(1-\alpha_{n}\right)\right)+\rho_{n}-\log \left(\frac{\varepsilon}{\varepsilon-1}\right)\right)}{\sigma+\eta+(1-\sigma) \alpha_{n}-1+\alpha_{n}} & \rho_{m}=-\log (\gamma)+a_{1} \\
v_{y+1}^{m}=-\frac{a_{2} \sigma}{\nu} & \rho_{n}=-\log (\chi) \\
v_{y}^{m}=\frac{\sigma}{\nu} & \rho_{c}=-\log (\beta) \\
v_{c}^{m}=-\frac{a_{2} \rho_{c}+\rho_{m}}{\nu} & a_{1}=\log \left(1-e^{-\frac{1}{\beta}}\right)-\frac{\frac{1}{\beta}}{e^{\frac{1}{\beta}}-1} \\
& a_{2}=\frac{1}{e^{\frac{1}{\beta}}-1}
\end{array}
$$

\subsection{Euro area data}

To make output and real money balances stationary, we use first log differences, as in Adolfson et al. (2008). In our model of the Eurozone, $\hat{\pi}_{t}$ is the log-linearized inflation rate measured as the yearly log difference of GDP Deflator between one quarter and the same quarter of the previous year, $\hat{y}_{t}$ is the log-linearized output measured as the yearly log difference of GDP between one quarter and the same quarter of the previous year, and $\hat{\imath}_{t}$ is the short-term (3-month) nominal interest rate. These data are extracted from the Euro area Wide Model (AWM) database of Fagan et al. (2001). $\widehat{m p}_{t}$ is the log-linearized real money balances measured as the yearly log difference of real money between one quarter and the same quarter of the previous year, where real money is measured as the log difference between the money stock and the GDP Deflator. We use the M3 monetary aggregate 

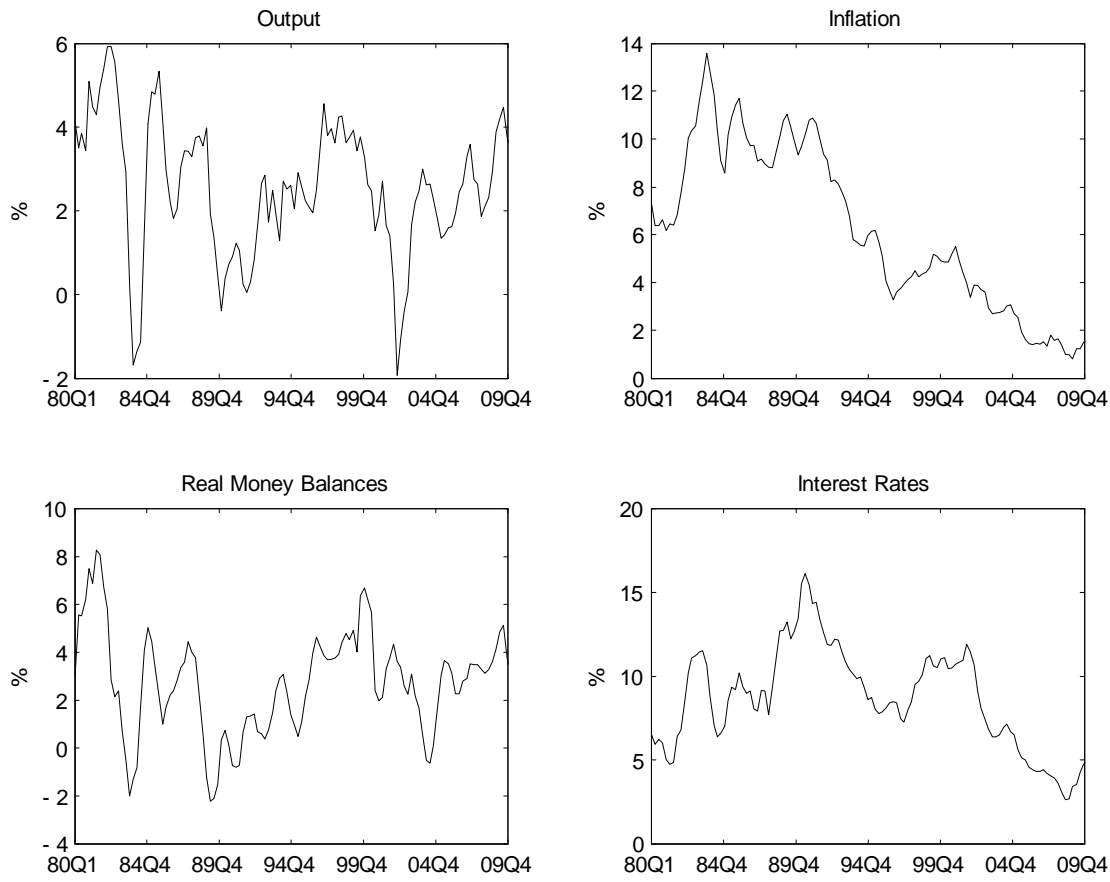

Figure 1: Euro area data (source: AWM and Eurostat)

from the Eurostat database. $\hat{y}_{t}^{f}$, the flexible-price output, $\widehat{m p}_{t}^{f}$, the flexibleprice real money balances, and $\hat{\imath}_{t}^{f}$, the flexible-price (natural) interest rate, are completely determined by structural shocks.

We deal with four historical variables (Fig. 1) described latter and four shocks: a preference shock $\left(\varepsilon_{t}^{p}\right)$, a money demand shock $\left(\varepsilon_{t}^{m}\right)$, a technology $\operatorname{shock}\left(\varepsilon_{t}^{a}\right)$ and a monetary policy shock $\left(\varepsilon_{t}^{i}\right)$. 


\subsection{Calibration and estimations}

We calibrate our model following Galí (2008), such that $\beta=0.99$ (discount factor), $\eta=1$ (inverse of the Frisch elasticity), and $\varepsilon=6$ (elasticity of demand of households for consumption goods). These parameters are calibrated while other parameters are estimated with Bayesian techniques ${ }^{2}$.

Calibration and estimation of structural parameters

\begin{tabular}{|c|c|c|c|c|c|c|c|c|}
\hline \multicolumn{9}{|c|}{ (decreasing return to scale) } \\
\hline & \multicolumn{3}{|c|}{ Priors } & \multicolumn{5}{|c|}{ Posteriors } \\
\hline & Law & Mean & Std. & Mean & t-stat & Std. & $5 \%$ & $95 \%$ \\
\hline$\alpha_{n}$ & beta & 0.50 & 0.15 & 0.6430 & 12.85 & 0.0494 & 0.563 & 0.721 \\
\hline$\alpha_{m}$ & beta & 0.50 & 0.15 & 0.0646 & 2.156 & 0.0256 & 0.022 & 0.105 \\
\hline$\theta$ & beta & 0.66 & 0.05 & 0.8029 & 29.26 & 0.0278 & 0.755 & 0.848 \\
\hline$v$ & normal & 2.00 & 0.10 & 2.1395 & 22.66 & 0.0941 & 1.987 & 2.294 \\
\hline$\sigma$ & normal & 2.00 & 0.10 & 1.8545 & 09 & 0.0970 & 1.692 & 2.010 \\
\hline$\gamma$ & beta & 0.25 & 0.10 & 0.2507 & 2.096 & 0.1041 & 0.085 & 0.406 \\
\hline$\chi$ & beta & 0.25 & 0.10 & 0.2565 & 2.220 & 0.1020 & 0.095 & 0.410 \\
\hline$\lambda_{i}$ & beta & 0.50 & 0.10 & 0.4750 & 9.323 & 0.0513 & 0.388 & 0.557 \\
\hline$\lambda_{\pi}$ & normal & 3.00 & 0.20 & 3.2021 & 16.40 & 0.1937 & 2.886 & 3.523 \\
\hline$\lambda_{x}$ & normal & 1.50 & 0.20 & 1.8060 & 10.27 & 0.1764 & 1.507 & 2.094 \\
\hline$\rho_{a}$ & beta & 0.75 & 0.10 & 0.9251 & 37.53 & 0.0247 & 0.886 & 0.964 \\
\hline$\rho_{p}$ & beta & 0.75 & 0.10 & 0.9135 & 64.30 & 0.0142 & 0.889 & 0.936 \\
\hline$\rho_{i}$ & beta & 0.75 & 0.10 & 0.9914 & 301.7 & 0.0033 & 0.985 & 0.997 \\
\hline$\rho_{m}$ & beta & 0.75 & 0.10 & 0.9412 & 54.10 & 0.0174 & 0.912 & 0.969 \\
\hline$\sigma_{a}$ & invgamma & 0.02 & 2.00 & 0.0072 & 14.09 & 0.0005 & 0.006 & 0.008 \\
\hline$\sigma_{i}$ & invgamma & 0.02 & 2.00 & 0.0065 & 8.092 & 0.0008 & 0.005 & 0.007 \\
\hline$\sigma_{p}$ & invgamma & 0.02 & 2.00 & 0.0992 & 6.943 & 0.0138 & 0.075 & 0.122 \\
\hline$\sigma_{m}$ & invgamma & 0.02 & 2.00 & 0.0230 & 13.57 & 0.0017 & 0.020 & 0.025 \\
\hline
\end{tabular}

Table 1: Bayesian estimation of the model

The estimation of the implied posterior distribution of the parameters (Table 1) is conducted using the Metropolis-Hastings algorithm ${ }^{3}$ (10 chains, each of 100000 draws).

\footnotetext{
${ }^{2}$ See Appendix 7.B for the detailed calibration exercise.

${ }^{3}$ See for instance Smets and Wouters (2003), Smets and Wouters (2007), Adolfson et al. (2007), and Adolfson et al. (2008).
} 
The real money balances parameter $\left(\alpha_{m}\right)$ of the augmented production function is estimated to 0.064. This result is in line with Sinai and Stokes (1972). They obtain a value of 0.087 for the same parameter and they also considering M3. The prior and posterior distributions are in Appendix 7.C.1 and estimates of the macro-parameters (aggregated structural parameters) are provided in Appendix 7.E.

As in Table 1, we use Bayesian techniques to estimate our model with money in the production function and a supplementary restriction. This restriction is adopted from Short (1979) and involves the hypothesis of constant returns to scale of the production function. Then, we assume that $\alpha_{n}=\alpha_{m}$ and we test our model with this hypothesis.

Calibration and estimation of structural parameters

\begin{tabular}{|c|c|c|c|c|c|c|c|c|}
\hline \multicolumn{9}{|c|}{ (constant return to scale) } \\
\hline & \multicolumn{3}{|c|}{ Priors } & \multicolumn{5}{|c|}{ Posteriors } \\
\hline & Law & Mean & Std. & Mean & t-stat & Std. & $5 \%$ & $95 \%$ \\
\hline$\alpha_{n}$ & beta & 0.50 & 0.15 & 0.5744 & 17.63 & 0.0320 & 0.519 & 0.625 \\
\hline$\theta$ & beta & 0.66 & 0.05 & 0.8388 & 35.52 & 0.0239 & 0.799 & 0.878 \\
\hline$v$ & normal & 2.00 & 0.10 & 2.3026 & 25.88 & 0.0887 & 2.158 & 2.450 \\
\hline$\sigma$ & normal & 2.00 & 0.10 & .7821 & 18.06 & 0.0986 & 1.619 & 1.944 \\
\hline$\gamma$ & beta & 0.25 & 0.1 & 0.24 & 2.096 & 0.1 & 0.085 & 0.403 \\
\hline$\chi$ & beta & 0.25 & 0.10 & 0.29 & 2.529 & 0.1 & 0.134 & 0.463 \\
\hline$\lambda_{i}$ & beta & 0.50 & 0.10 & 0.5432 & 10.74 & 0.0 & 0.458 & 0.629 \\
\hline$\lambda_{\pi}$ & normal & 3.00 & 0.20 & 3.2002 & 16.27 & 0.1955 & 2.876 & 3.515 \\
\hline$\lambda_{x}$ & normal & 1.50 & 0.20 & 1.7647 & 10.09 & 0.1756 & 1.473 & 2.053 \\
\hline$\rho_{a}$ & beta & 0.75 & 0.10 & 0.9169 & 32.79 & 0.0280 & 0.874 & 0.960 \\
\hline$\rho_{p}$ & beta & 0.75 & 0.10 & 0.9056 & 58.20 & 0.0156 & 0.880 & 0.931 \\
\hline$\rho_{i}$ & beta & 0.75 & 0.10 & 0.9907 & 271.7 & 0.0037 & 0.984 & 0.997 \\
\hline$\rho_{m}$ & beta & 0.75 & 0.10 & 0.9480 & 57.74 & 0.0165 & 0.921 & 0.974 \\
\hline$\sigma_{a}$ & invgamma & 0.02 & 2.00 & 0.0076 & 13.91 & 0.0005 & 0.006 & 0.008 \\
\hline$\sigma_{i}$ & invgamma & 0.02 & 2.00 & 0.0059 & 7.101 & 0.0008 & 0.004 & 0.007 \\
\hline$\sigma_{p}$ & invgamma & 0.02 & 2.00 & 0.0966 & 7.034 & 0.0132 & 0.073 & 0.118 \\
\hline$\sigma_{m}$ & invgamma & 0.02 & 2.00 & 0.0238 & 13.75 & 0.0017 & 0.021 & 0.026 \\
\hline
\end{tabular}

Table 2: Bayesian estimation of the model with constant return to scale

The resulting log marginal density for the model without constant returns to scale $(-512.93)$ and for the model with constant returns to scale $(-557.52)$ 
indicates that, if we admit that money enters the production function, this production function should have decreasing returns to scale.

Robustness diagnosis about the numerical maximization of the posterior kernel are also computed and indicates that the optimization procedure leads to a robust maximum for the posterior kernel. The convergence of the proposed distribution to the target distribution is satisfied. A diagnosis of the overall convergence for the Metropolis-Hastings sampling algorithm is provided in Appendix 7.D.

\section{Simulations}

\subsection{Impulse response functions}

Fig. 2 presents the response of key variables to structural shocks. The thin solid line represents the decreasing return-to-scale model responses and the dashed line represents the constant return-to-scale model responses.

In response to a preference shock, the inflation rate, the output, the output gap, the real money balances, the nominal and the real interest rates rise; real money growth displays a little overshooting process in the first periods, then returns quickly to its steady-state value.

After a technology shock, the output gap, the inflation rate, the nominal and the real interest rates decrease, whereas output as well as real money balances and real money growth rise.

Following a money shock, inflation, output, real and nominal interest rates and the output gap dynamics differs depending on the model. The model of decreasing returns to scale displays more coherent results than that of constant returns to scale.

In response to an interest rate shock, the inflation rate, the nominal interest rate, the output and the output gap fall. The real interest rate rises. A positive monetary policy shock induces a fall in interest rates due to a low enough degree of intertemporal substitution (i.e., the risk aversion parameter is high enough), which generates a large impact response of current consumption relative to future consumption. This result has been noted in, inter alia, Jeanne (1994) and Christiano et al. (1997). 

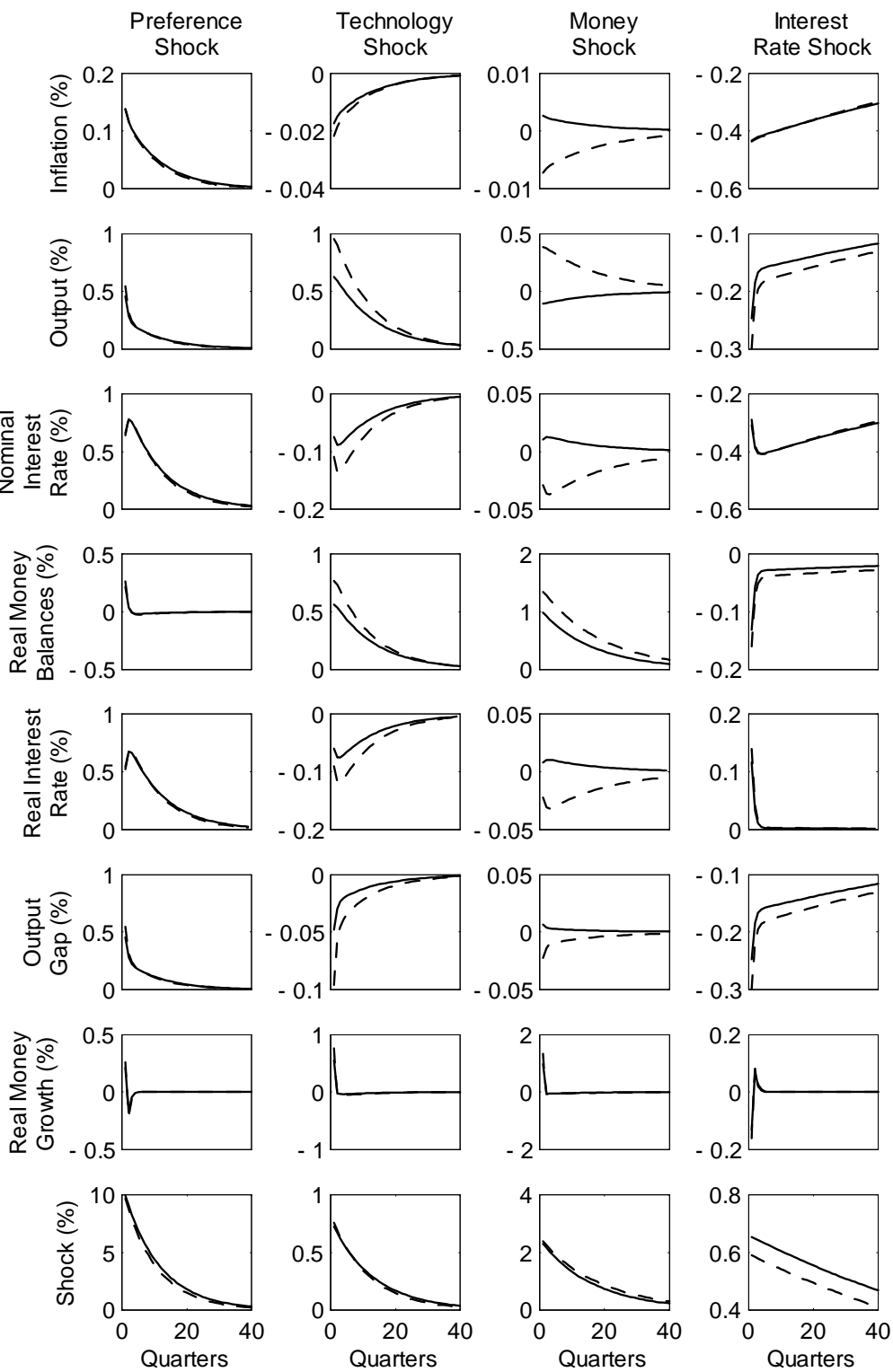

Figure 2: Impulse response functions to structural shocks 


\subsection{Variance decompositions}

We analyze in two different ways the forecast error variance of each variable following exogenous shocks: using constant returns to scale and decreasing returns to scale. The analysis is conducted first via an unconditional variance decomposition (Table 3 ) and second via a conditional variance decomposition (Fig. 3 to 5) to compare the two models' dynamics of variance decomposition over time.

Unconditional variance decomposition (\%)

\begin{tabular}{|c|c|c|c|c|c|c|c|c|}
\hline & \multicolumn{4}{|c|}{ with decreasing returns to scale } & \multicolumn{4}{|c|}{ with constant returns to scale } \\
\hline & $\varepsilon_{t}^{p}$ & $\varepsilon_{t}^{i}$ & $\varepsilon_{t}^{m}$ & $\varepsilon_{t}^{a}$ & $\varepsilon_{t}^{p}$ & $\varepsilon_{t}^{i}$ & $\varepsilon_{t}^{m}$ & $\varepsilon_{t}^{a}$ \\
\hline$y_{t}$ & 10.92 & 31.29 & 2.07 & 55.72 & 6.5 & 19.08 & 15.06 & 59.37 \\
\hline$\pi_{t}$ & 0.9 & 99.08 & 0 & 0.02 & 0.9 & 99.07 & 0 & 0.02 \\
\hline$i_{t}$ & 31.08 & 68.45 & 0.01 & 0.46 & 31.83 & 67 & 0.12 & 1.05 \\
\hline$m p_{t}$ & 0.47 & 0.64 & 77.14 & 21.76 & 0.34 & 0.52 & 80.94 & 18.2 \\
\hline$y_{t}^{f}$ & 0 & 0 & 3.5 & 96.5 & 0 & 0 & 19.37 & 80.63 \\
\hline$m p_{t}^{f}$ & 0 & 0 & 76.45 & 23.55 & 0 & 0 & 80.12 & 19.88 \\
\hline
\end{tabular}

Table 3: Variance decomposition of the model

Adding the constant returns-to-scale restriction gives a larger role to real money demand in explaining the variance of output. Moreover, its radically changes the variance decomposition of output and its flexible-price counterpart, whereas the variance decomposition of other variables are almost unchanged.

For the two models, most of the output's variance comes from the technology shock, about a quarter of the variance of output results from the interest rate shock (31.29\% for the decreasing returns case, and $19.08 \%$ for the constant returns case) and the remaining quarter from the other shocks. For the decreasing returns case, if money demand plays a role, its role is rather minor (an impact of less than 2.1\%) and insignificant.

Moreover, Table 3 shows that assuming constant returns to scale gives money (demand) a role. As in Moghaddam (2010), the variance decomposition indicates that money supply is capable of explaining some of the forecasting error variance of real output. This is the case only for the constant returns to scale model. 
As Table 3 shows, the money shock contribution to the business cycle depends on the returns to scale hypothesis.
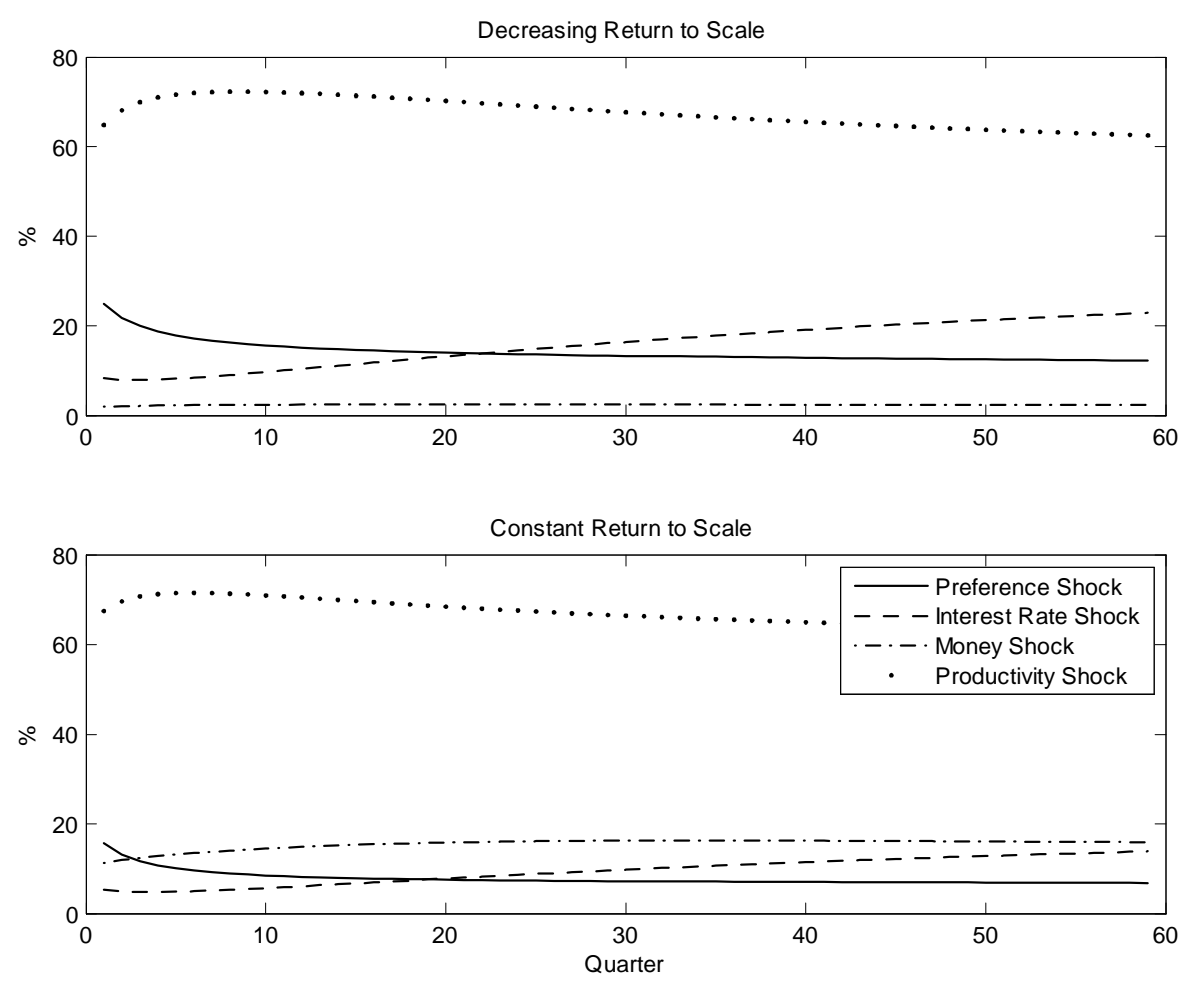

Figure 3: Forecast error variance decomposition of output

If approximately half of the variance of output is still explained by the productivity shock, the role of the preference shock decreases notably, whereas the impact of the interest rate shock increases over time. Figure 3 also confirms the significant role of money (demand) in the dynamics of output, and its increasing role over periods, under the constant returns to scale hypothesis.

A look at the conditional and unconditional inflation variance decompositions shows the overwhelming role of the interest rate shock which explains more than $96 \%$ of the inflation rate's variance. As there is no significant change over the two models, we don't represent this decomposition. 

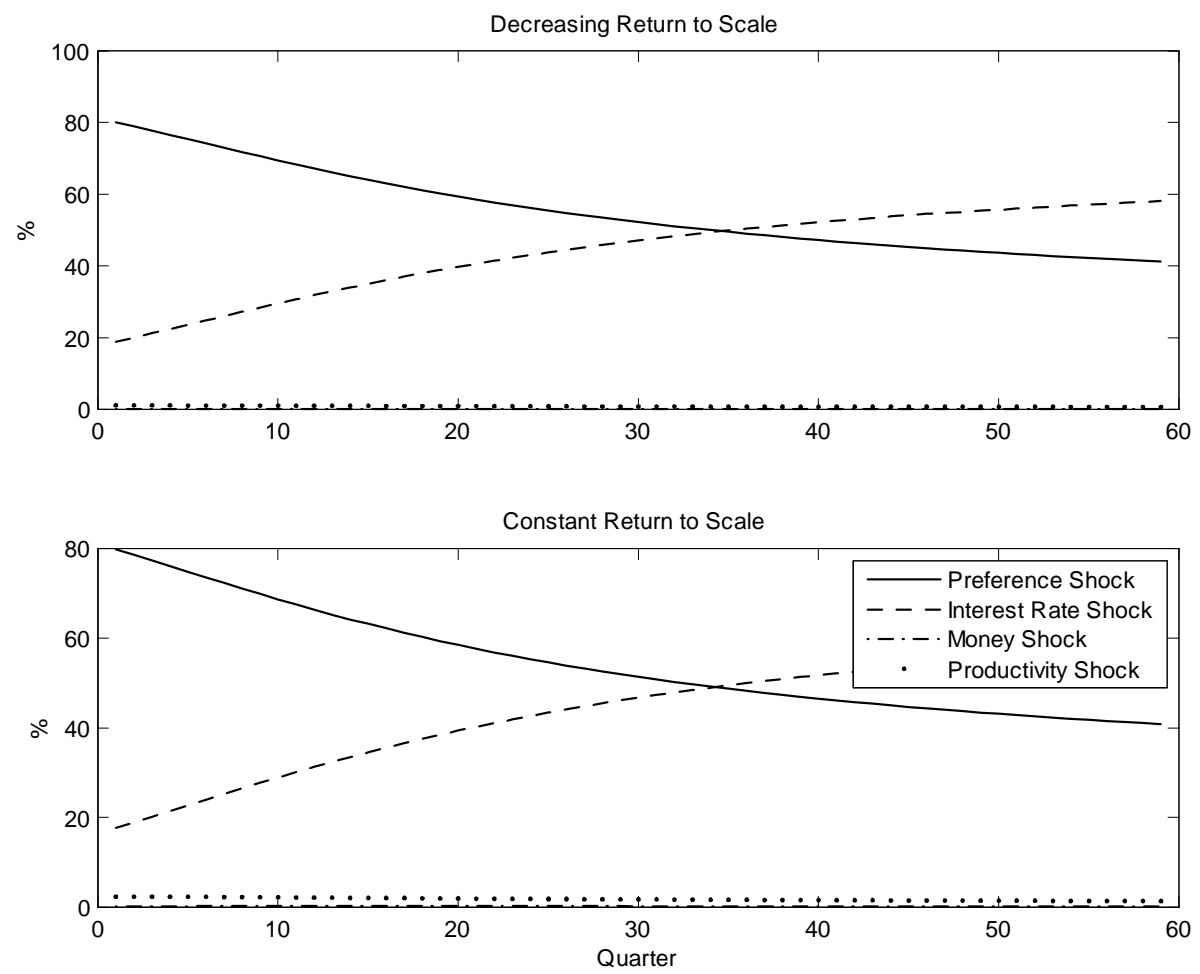

Figure 4: Forecast error variance decomposition of interest rate

The variance of the nominal interest rate is dominated by the direct shock to the interest rate. The relative importance of each of these shocks changes through time (Fig. 4). Over short horizons, the preference shock explains almost $70 \%$ of the nominal interest rate variance, whereas the interest rate shock explains less than 20\%. For longer horizons, there is an inversion: the nominal interest rate shock explains close to $70 \%$ of the variance, and the preference shock explains a bit more than $20 \%$.

Table 3 as well as the conditional variance decomposition of real money balances shows that real money balances are mainly explained by the real money balances shock and the technology shock. As there is no significant change over the two models, we don't represent this decomposition. 

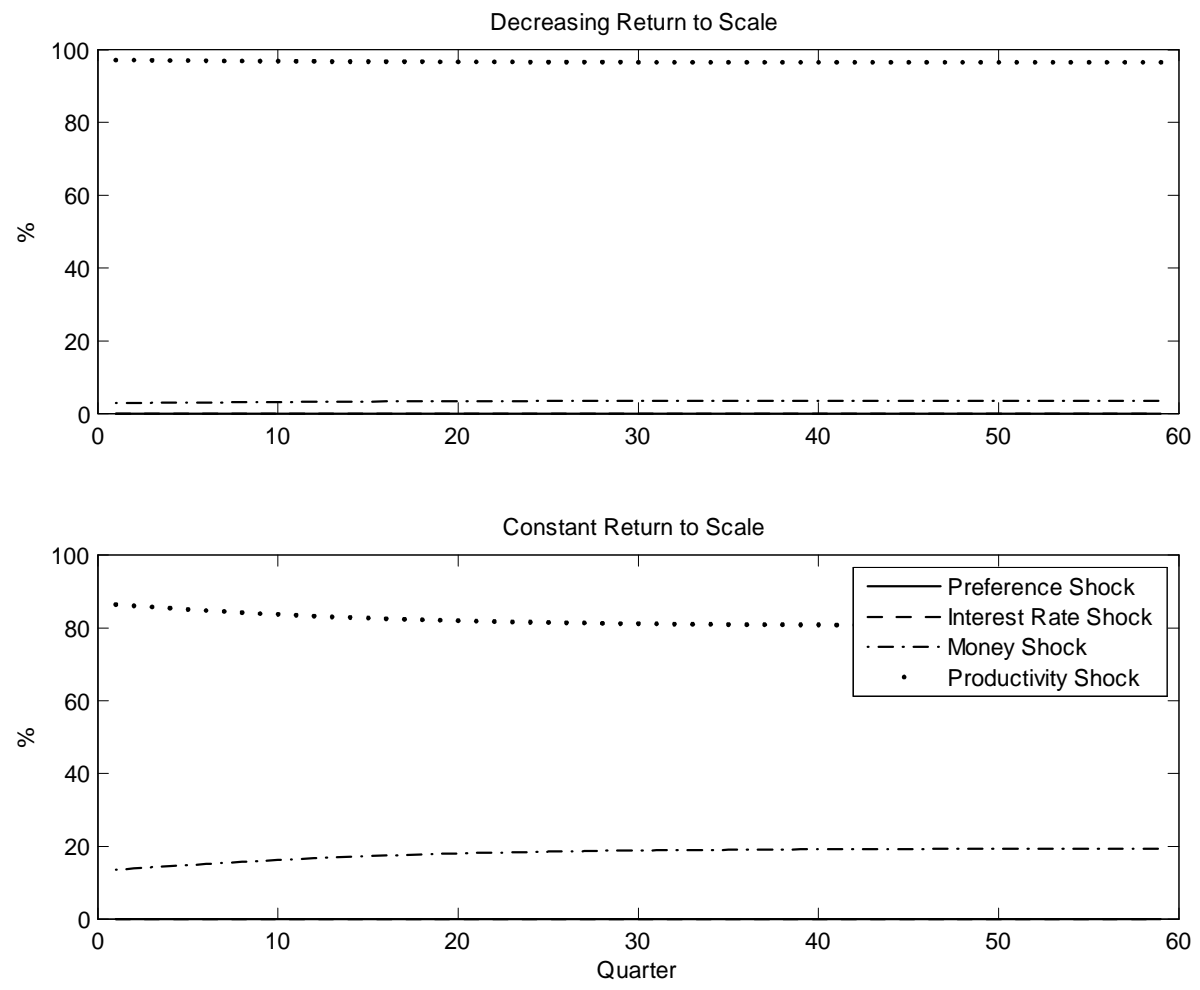

Figure 5: Forecast error variance decomposition of flexible-price output

It is also interesting to note that the same type of analysis applies to the flexible-price output variance decomposition (Fig. 5). Productivity, with a weight greater than $85 \%$, is the main explanatory factor, while other shocks play minor roles.

As the flexible-price real money balances variance is mainly explained by the money shock, with a significant impact of the productivity shock, the impact of each of these shocks does not change through time, so we don't represent this decomposition either.

\section{Interpretation}

The constant returns-to-scale hypothesis gives money (demand) a more important role than does the decreasing returns to scale hypothesis. Following the log-marginal density criteria, the decreasing returns to scale hypothesis is preferred to the constant returns to scale hypothesis. 
This result disproves the hypothesis of Short (1979), Startz (1984), Benzing (1989), and Chang (2002) of constant returns to scale for money in the production function and confirms the hypothesis of Khan and Ahmad (1985) (decreasing returns).

This criterion gives no significant role to money (demand) in the dynamics of the variables, despite its introduction in the production function.

The simulation results are close to those obtained in the Galí (2008) baseline model and provide interesting results about the potential effect of money on output and flexible-price output under the constant returns to scale hypothesis. Interestingly, and even if money enters the inflation equation, the variance decomposition of inflation with respect to shocks is unaffected under the two hypotheses.

\section{Conclusion}

One of the most unsettled issues of the postwar economic literature involves the role of money as a factor of production. The notion of money as a factor of production has been debated both theoretically and empirically by a number of researchers in the past five decades. The question is whether money is an omitted variable in the production process.

However, empirical support for money as an input along with labor (and capital) has been mixed and, thus, the issue appears to be unsettled. Recent developments involve a reexamination of the role of money (demand) in the production function. One of these development is the New Keynesian DSGE theory mixed with Bayesian analysis.

We depart from existing theoretical (and empirical) New Keynesian literature by building a New Keynesian DSGE model à la Galí (2008) that includes money in the production function, displaying money in the inflation equation. Closing the model leads to the new concept of flexible-price real money balances.

Despite their inclusion in the production function, and at least in the unconstrained estimation, real money holdings do not play a significant role in the dynamics of the system. The only way to ascribe a role for real money demand in the dynamics of the system is to assume constant returns to scale to factors of production, which is a strong and controversial hypothesis.

Moreover, we confirm that the model with decreasing returns to scale is better than the model with constant returns to scale. Under decreasing returns to scale, real money holdings do not play a significant role in the dynamics of the economy. We also show that adding a money component to the system does not necessarily create a role for it. 
In this model, money demanded by households is also used (by them, as firms' owners) as an input in production. But an issue of rival use (in facilitating transactions) would emerge. That is why for further research, as in Benhabib et al. (2001), a distinction between money for productive and nonproductive use seems warranted. This perspective could enlarge our money channel consideration.

\section{Appendix}

\section{A Optimization problem}

Our Lagrangian is given by

$$
L_{t}=E_{t}\left[\sum_{k=0}^{\infty} \beta^{k} U_{t+k}-\lambda_{t+k} V_{t+k}\right]
$$

where

$$
V_{t}=C_{t}+\frac{M_{t}}{P_{t}}+Q_{t} \frac{B_{t}}{P_{t}}-\frac{B_{t-1}}{P_{t}}-\frac{W_{t}}{P_{t}} N_{t}-\frac{M_{t-1}}{P_{t}}
$$

and

$$
U_{t}=e^{\varepsilon_{t}^{p}}\left(\frac{C_{t}^{1-\sigma}}{1-\sigma}+\frac{\gamma e^{\varepsilon_{t}^{m}}}{1-\nu}\left(\frac{M_{t}}{P_{t}}\right)^{1-\nu}-\frac{\chi N_{t}^{1+\eta}}{1+\eta}\right)
$$

The first order condition related to consumption expenditures is given by

$$
\lambda_{t}=e^{\varepsilon_{t}^{p}} C_{t}^{-\sigma}
$$

where $\lambda_{t}$ is the Lagrangian multiplier associated with the budget constraint at time $t$.

The first order condition corresponding to the demand for contingent bonds implies that

$$
\lambda_{t} \frac{Q_{t}}{P_{t}}=\beta E_{t}\left[\frac{\lambda_{t+1}}{P_{t+1}}\right]
$$

The demand for cash that follows from the household's optimization problem is given by

$$
\gamma e^{\varepsilon_{t}^{p}} e^{\varepsilon_{t}^{m}}\left(\frac{M_{t}}{P_{t}}\right)^{-\nu}=\lambda_{t}-\beta E_{t}\left[\lambda_{t+1} \frac{P_{t}}{P_{t+1}}\right]
$$

which can be naturally interpreted as a demand for real balances. The latter is increasing in consumption and is inversely related to the nominal interest 
rate, as in conventional specifications.

$$
\chi e^{\varepsilon_{t}^{p}} N_{t}^{\eta}=\lambda_{t} \frac{W_{t}}{P_{t}}
$$

We obtain from eq. (32)

$$
\lambda_{t}=e^{\varepsilon_{t}^{p}} C_{t}^{-\sigma} \Leftrightarrow U_{c, t}=e^{\varepsilon_{t}^{p}} C_{t}^{-\sigma}
$$

where $U_{c, t}=\left.\frac{\partial U_{k, t}}{\partial C_{t+k}}\right|_{k=0}$. Eq. (36) defines the marginal utility of consumption.

Hence, the optimal consumption/savings, real money balances and labor supply decisions are described by the following conditions:

- Combining (32) with (33) gives

$$
Q_{t}=\beta E_{t}\left[\frac{e^{\varepsilon_{t+1}^{p}} C_{t+1}^{-\sigma}}{e^{\varepsilon_{t}^{p}} C_{t}^{-\sigma}} \frac{P_{t}}{P_{t+1}}\right] \Leftrightarrow Q_{t}=\beta E_{t}\left[\frac{U_{c, t+1}}{U_{c, t}} \frac{P_{t}}{P_{t+1}}\right]
$$

where $U_{c, t+1}=\left.\frac{\partial U_{k, t}}{\partial C_{t+k}}\right|_{k=1}$. Eq. (37) is the usual Euler equation for intertemporal consumption flows. It establishes that the ratio of marginal utility of future and current consumption is equal to the inverse of the real interest rate.

- Combining eq. (32) and eq. (34) gives

$$
\gamma \frac{e^{\varepsilon_{t}^{m}}}{C_{t}^{-\sigma}}\left(\frac{M_{t}}{P_{t}}\right)^{-\nu}=1-Q_{t} \Leftrightarrow \frac{U_{m, t}}{U_{c, t}}=1-Q_{t}
$$

where $U_{m, t}=\left.\frac{\partial U_{k, t}}{\partial\left(M_{t+k} / P_{t+k}\right)}\right|_{k=0}$. Eq. (38) is the intertemporal optimality condition setting the marginal rate of substitution between money and consumption equal to the opportunity cost of holding money.

- And combining eq. (32) and eq. (35) gives

$$
\chi \frac{N_{t}^{\eta}}{C_{t}^{-\sigma}}=\frac{W_{t}}{P_{t}} \Leftrightarrow \frac{U_{n, t}}{U_{c, t}}=-\frac{W_{t}}{P_{t}}
$$

where $U_{n, t}=\left.\frac{\partial U_{k, t}}{\partial N_{t+k}}\right|_{k=0}$. Eq. (39) is the condition for the optimal consumption-leisure arbitrage, implying that the marginal rate of substitution between consumption and labor is equal to the real wage. 


\section{B Calibration}

We estimate all parameters, except the discount factor $(\beta)$, the inverse of the Frisch elasticity of labor supply $(\eta)$, and the elasticity of demand of households for consumption goods $(\varepsilon)$.

Following standard conventions, we calibrate beta distributions for parameters that fall between zero and one, inverted gamma distributions for parameters that need to be constrained to be greater than zero and normal distributions in other cases.

As our goal is to compare two models, we adopt the same priors in the two models with the same calibration, except for the return to scale parameter. The calibration of $\sigma$ is inspired by Rabanal and Rubio-Ramírez (2005) and Casares (2007). They choose, respectively, a risk aversion parameter of 2.5 and 1.5. In line with these values, we consider that $\sigma=2$ corresponds to a standard risk aversion, as in Benchimol and Fourçans (2012).

As in Smets and Wouters (2003), the standard errors of the innovations are assumed to follow inverse gamma distributions, and we choose a beta distribution for shock persistence parameters (as well as for the backward component of the Taylor rule, scale parameters, $\gamma$ and $\chi$, price stickiness index, $\theta$, and output elasticities of labor, $\alpha_{n}$, and of real money balances, $\alpha_{m}$, of the production function) that should be lesser than one.

The calibration of $\alpha, \beta, \theta, \eta$ and $\varepsilon$ comes from Casares (2007) and Galí (2008). The smoothed Taylor rule $\left(\lambda_{i}, \lambda_{\pi}\right.$, and $\left.\lambda_{x}\right)$ is calibrated following Gerlach-Kristen (2003), with priors analogous to those used by Smets and Wouters (2003). In order to take into consideration possible behaviors of the central bank, we assign a higher standard error for the Taylor rule coefficients.

All the standard errors of shocks are assumed to be distributed according to inverted Gamma distributions, with prior means of 0.02. The latter law ensures that these parameters have a positive support. The autoregressive parameters are all assumed to follow Beta distributions. All these distributions are centered around 0.75 and we take a common standard error of 0.1 for the shock persistence parameters, as in Smets and Wouters (2003). 


\section{Priors and posteriors}

C.1 Model with decreasing returns to scale
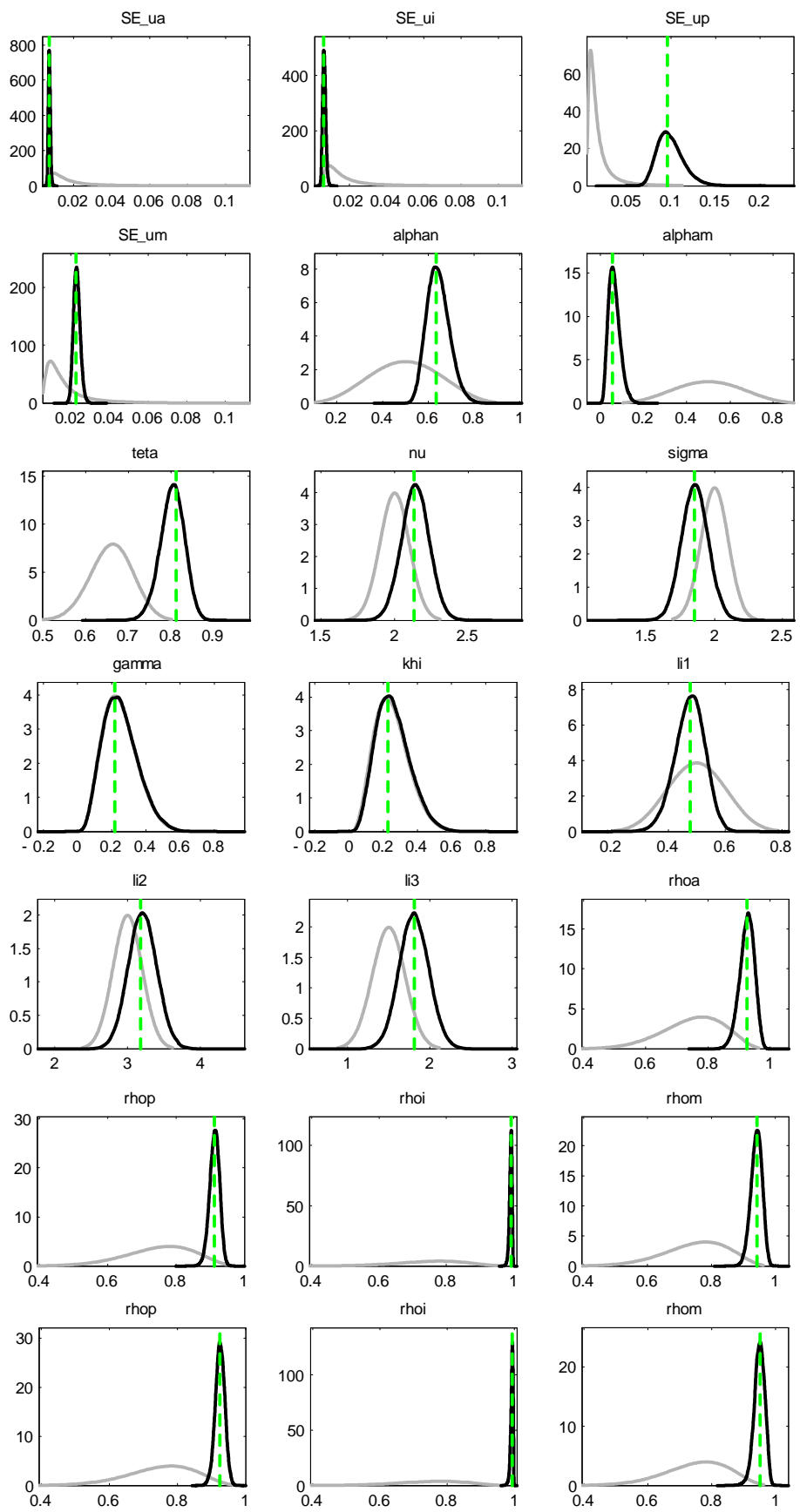
C.2 Model with constant returns to scale
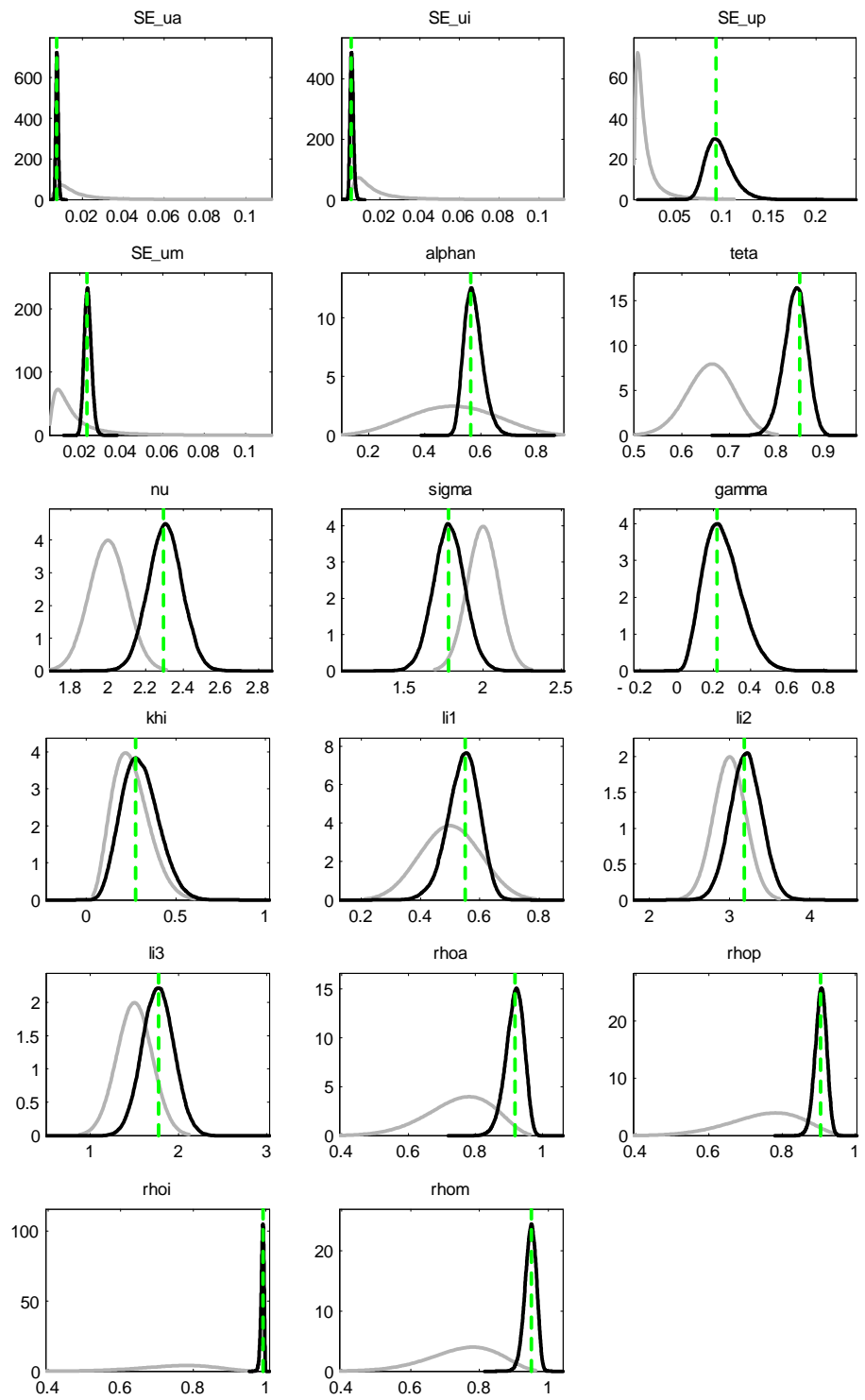


\section{Robustness checks}

Each graph represents specific convergence measures with two distinct lines that show the results within (red line) and between (blue line) chains (Geweke, 1999). Those measures are related to the analysis of the model parameters mean (interval), variance ( $\mathrm{m} 2)$ and third moment $(\mathrm{m} 3)$. For each of the three measures, convergence requires that both lines become relatively horizontal and converge to each other in both models ${ }^{4}$.

\section{D.1 Model with decreasing returns to scale}
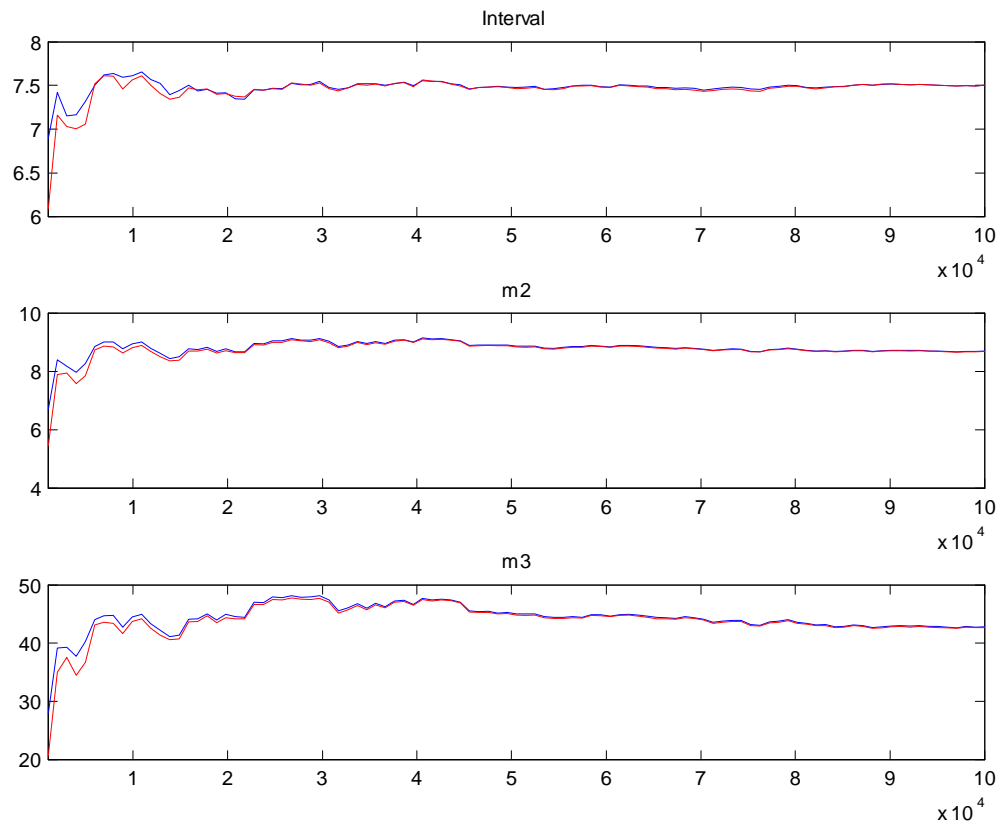

\footnotetext{
${ }^{4}$ Robustness analysis with respect to calibrated parameters is available upon request.
} 


\section{D.2 Model with constant returns to scale}
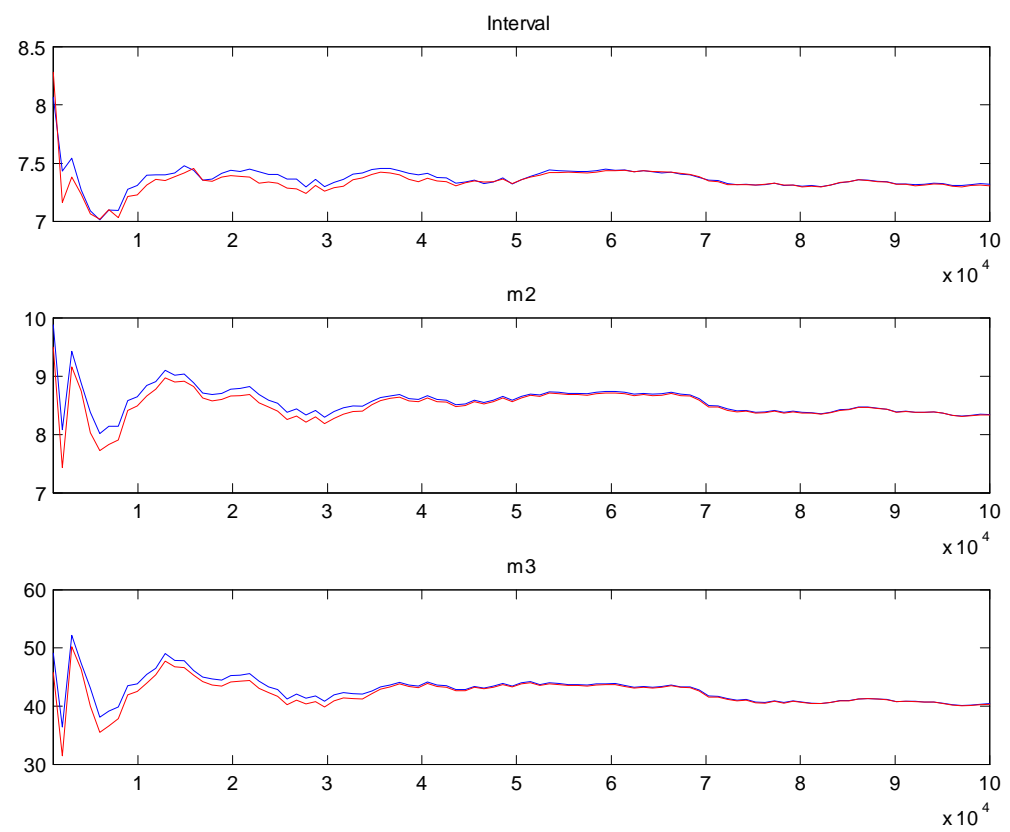

\section{E Macro parameters}

$\begin{array}{rcc} & \begin{array}{c}\text { Decreasing } \\ \text { returns to scale }\end{array} & \begin{array}{c}\text { Constant } \\ \text { returns to scale }\end{array} \\ v_{a}^{y} & 1.026665 & 1.048629 \\ v_{m}^{y} & -0.116906 & 0.379180 \\ v_{c}^{y} & -0.085881 & 0.221747 \\ v_{y+1}^{m} & -0.496467 & -0.443291 \\ v_{y}^{m} & 0.866771 & 0.773933 \\ v_{c}^{m} & 0.167187 & 0.157893 \\ \frac{1}{\nu} & 0.467391 & 0.434287 \\ \kappa_{x} & 0.047323 & 0.047126 \\ \kappa_{m} & 0.005532 & -0.017869 \\ \sigma^{-1} & 0.539232 & 0.561143 \\ \rho_{c} & -0.010050 & -0.010050 \\ \frac{\sigma}{\nu} & 0.866771 & 0.773933 \\ \frac{a_{2}}{\nu} & 0.164496 & 0.155393 \\ \frac{\rho_{m}}{\nu} & 0.467391 & 0.434287 \\ \lambda_{\pi}\left(1-\lambda_{i}\right) & 1.681117 & 1.461802 \\ \lambda_{x}\left(1-\lambda_{i}\right) & 0.948134 & 0.806101 \\ \lambda_{i} & 0.475001 & 0.543219\end{array}$




\section{References}

Adolfson, M., Laseen, S., Linde, J., Villani, M., 2007. Bayesian estimation of an open economy DSGE model with incomplete pass-through. Journal of International Economics 72 (2), 481-511.

Adolfson, M., Laseen, S., Linde, J., Villani, M., 2008. Evaluating an estimated new Keynesian small open economy model. Journal of Economic Dynamics and Control 32 (8), 2690-2721.

Ben-Zion, U., and Ruttan, V.W., 1975. Money in the production function: an interpretation of empirical results. The Review of Economics and Statistics 57(2), 246-247.

Benchimol, J., and Fourçans, A., 2012. Money and risk in a DSGE framework: a Bayesian application to the Eurozone. Journal of Macroeconomics 34(1), 95-111.

Benhabib, J., Schmitt-Grohé, S., and Uribe, M., 2001. Monetary policy and multiple equilibria. American Economic Review 91(1), 167-186.

Benzing, C., 1989. An update on money in the production function. Eastern Economic Journal 15(3), 235-239.

Calvo, G.A., 1983. Staggered prices in a utility-maximizing framework. Journal of Monetary Economics 12(3), 383-398.

Casares, M., 2007. Monetary policy rules in a new Keynesian Euro area model. Journal of Money, Credit and Banking 39 (4), 875-900.

Chang, W., 2002. Examining the long-run effect of money on economic growth: an alternative view. Journal of Macroeconomics 24(1), 81-102.

Clarida, R., Galí, J., and Gertler, M., 1999. The science of monetary policy: a new Keynesian perspective. Journal of Economic Literature 37(4), 16611707.

Cobb, C.W., and Douglas, P.H., 1928. A theory of production. American Economic Review 18(1), 139-165.

Christiano, L., Eichenbaum, M., Evans, C., 1997. Sticky price and limited participation models of money: a comparison. European Economic Review 41(6), 1201-1249. 
Fagan, G., Henry, J., Mestre, R., 2001. An Area-Wide Model (AWM) for the Euro area. European Central Bank Working Paper No. 42.

Fischer, S., 1974. Money and the production function. Economic Inquiry 12(4), 517-33.

Friedman, M., 1959. The demand for money: some theoretical and empirical results. Journal of Political Economy 64(1), 327-351.

Friedman, M., 1969. The optimum quantity of money and other essays. Chicago: Aldine Publishing Co.

Galí, J., 2008. Monetary policy, inflation and the business cycle: an introduction to the new Keynesian framework. Princeton University Press, Princeton, NJ.

Gerlach-Kristen, P., 2003. Interest rate reaction functions and the Taylor rule in the Euro area. European Central Bank Working Paper No. 258.

Geweke, J., 1999. Using simulation methods for Bayesian econometric models: inference, development, and communication. Econometric Reviews 18 (1), 1-73.

Hasan, M.A., and Mahmud, S.F., 1993. Is money an omitted variable in the production function? Some further results. Empirical Economics 18(3), 431-445.

Ireland, P.N., 2004. Money's role in the monetary business cycle. Journal of Money, Credit and Banking 36(6), 969-983.

Jeanne, O., 1994. Nominal rigidities and the liquidity effect. Mimeo ENPCCERAS.

Johnson, H.G., 1969. Inside money, outside money, income, wealth and welfare in monetary theory. Journal of Money Credit and Banking 1(1), $30-45$.

Khan, A.H., and Ahmad, M., 1985. Real money balances in the production function of a developing country. The Review of Economics and Statistics 67(2), 336-340.

Levhari, D., and Patinkin, D., 1968. The role of money in a simple growth model. American Economic Review 58(4), 713-753. 
Moghaddam, M., 2010. Co-integrated money in the production functionevidence and implications. Applied Economics 42(8), 957-963.

Rabanal, P., Rubio-Ramírez, J.F., 2005. Comparing new Keynesian models of the business cycle: a Bayesian approach. Journal of Monetary Economics $52(6), 1151-1166$.

Sephton, P.S., 1988. Money in the production function revisited. Applied Economics 20(7), 853-860.

Short, E.D., 1979. A new look at real money balances as a variable in the production function. Journal of Money, Credit and Banking 11(3), 326339 .

Sinai, A., and Stokes, H.H., 1972. Real money balances: an omitted variable from the production function?. The Review of Economics and Statistics 54(3), 290-296.

Sinai, A., and Stokes, H.H., 1975. Real money balances: an omitted variable from the production function? A reply. The Review of Economics and Statistics 57(2), 247-252.

Sinai, A., and Stokes, H.H., 1977. Real money balances as a variable in the production function: reply. Journal of Money, Credit and Banking 9(2), 372-373.

Sinai, A., and Stokes, H.H., 1981. Real money balances in the production function: a comment. Eastern Economic Journal 17(4), 533-535.

Sinai, A., and Stokes, H.H., 1989. Money balances in the production function: a retrospective look. Eastern Economic Journal 15(4), 349-363.

Smets, F., and Wouters, R., 2003. An estimated Dynamic Stochastic General Equilibrium model of the Euro area. Journal of the European Economic Association 1(5), 1123-1175.

Smets, F., Wouters, R., 2007. Shocks and frictions in US business cycles: a Bayesian DSGE approach. American Economic Review 97 (3), 586 -606.

Startz, R., 1984. Can money matter ?. Journal of Monetary Economics 13(3), 381-385.

Stein, J.L., 1970. Monetary growth theory in perspective. American Economic Review 60(1), 85-106. 
Subrahmanyam, G., 1980. Real money balances as a factor of production: some new evidence. The Review of Economics and Statistics 62(2), 280283.

Walsh, C.E., 2010. Monetary theory and policy. The MIT Press, Cambridge, MA.

Woodford, M., 2003. Interest and prices: foundations of a theory of monetary policy. Princeton University Press, Princeton, NJ.

You, J.S., 1981. Money, technology, and the production function: an empirical study. The Canadian Journal of Economics 14(3), 515-524. 
ESSEC Business School Avenue Bernard Hirsch BP 50105

95021 Cergy-Pontoise Cedex

France

Tél. $+33(0) 134433000$

$\mathrm{Fax}+33(0) 134433001$

www.essec.fr

\section{ESSEC Executive Education} CNIT BP 230

92053 Paris-La Défense France

Têl. +33(0)146924900

Fax +33(0)1 46924990

http://formation.essec.fr

ESSEC Business School

Singapore Campus

100 Victoria Street

National Library Building \# 13-02

Singapore 188064

essecasia@essec.fr

Tél. +6568849780

Fax +6568849781

www.essec.edu

Informations

Alison Bougi

+33 (0)134433358

bougi@essec.fr

www.essec.fr

research.center@essec.fr

ISSN 1291-9616 